1 Department of Community Medicine, University Hospitals of Geneva, Switzerland

2 School of Dieticians, Geneva, Switzerland

\title{
Post-migration dietary changes among African refugees in Geneva: a rapid assessment study to inform nutritional interventions
}

Submitted: 7 January 2004

Accepted: 31 August 2004

\section{Summary}

Objectives: To conduct an assessment of perceived dietary changes and problems by African asylum seekers, in order to develop appropriate nutritional education interventions.

Methods: A cross-sectional qualitative study among a convenience sample. Analysis compared and contrasted reported dietary changes and migration-related difficulties.

Results: Nineteen interviews were analysed. After migration, main dietary changes were the decrease in different fruits and vegetables consumed weekly from 10 to 2 and 17 to 10 respectively. The number of respondents drinking sweetened beverages more than 3 times a week increased from 3 to 18 . Reasons for changes were related to prices, taste, choice and accessibility.

Conclusion: These dietary changes may have serious health consequences. Future remedial interventions based on suggestions of the respondents could easily be implemented.

Keywords: Dietary change - Asylum seekers - Nutrition education Cultural diversity - Fruit - Vegetable.

Exposure to western lifestyle increases unhealthy behaviours in migrants from poor to western countries (Misra 2000), and dietary changes are associated with increased risk of obesity, cardiovascular diseases and diabetes in migrant populations (Raymond \& D'Eramo-Melkus 1993; Sundquist \& Winkleby 2000; Trostler 1997; He et al. 1996). Conventional nutritional counselling is often inappropriate for migrants, due to different values attributed to food groups, mutual incomprehension about food items, meal organisation or preparation (Hargreaves et al. 2002; Satia-Abouta et al. 2002). Behavioural change in such patients is only likely when health care providers have competencies in multicultural nutrition counselling (Harris-Davis \& Haughton 2000; Curry 2000). In order to develop appropriate nutritional messages and interventions, it is important to first understand current beliefs and practices of the target population. At the dietetic consultation of the Geneva outpatient clinic (Department of community medicine - DMC) of the University Hospitals, almost $20 \%$ of the patients are of African origin, and most of them are asylum seekers or refugees. In addition, community health nurses working at the Health Centre for Migrants of the DMC report frequent complaints from African asylum seekers about weight gain, constipation and difficulties in cooking with local food items.

The purpose of this study was to explore perceived dietary changes and problems among African asylum seekers and refugees upon arrival in Geneva. This new knowledge was to be used to develop appropriate nutritional education interventions targeted at this ethnic group.

\section{Methods}

The study design was a cross-sectional, qualitative study (semi-structured interview), with a quantitative component (consumption frequency).

\section{Setting}

In Geneva, asylum seekers generally live from six months to several years in one of several dormitory-like asylum residences ("foyers"). Residents share kitchen and bathroom facilities, and have minimal space for storing food items. Housing and health insurance are provided free-of-charge 
to asylum seekers. At the time of the study (2001) they received a monthly allowance of $400 \mathrm{CHF}$ per adult and $200 \mathrm{CHF}$ per child, intended to cover all other expenses (324 and $162 €$ respectively).

\section{Study participants}

A non-random, convenience sample of 20 male and female African asylum seekers was constituted. Contact with participants was made through the nurses of the centre. Healthy volunteers above age 18, living in Geneva for less than eight months were eligible to the study. The second author visited them individually to explain the study objectives and obtained verbal informed consent before planning a second visit to conduct the interview.

\section{Data collection}

Semi-structured interviews were conducted at the home of the interviewee by the second author, previously trained by a medical anthropologist (PH) for this study. An interview guide was used to obtain information about dietary habits and food choices and the investigator let the interviewee talk freely. Probing questions focused at meal content, food frequencies and reasons for dietary changes after arrival in Geneva. These were discussed from the participant's point of view until no new information was generated (Satia et al. 2000). In addition, 24 hour dietary recalls were used to help participants remember commonly consumed foods and dishes and to crosscheck and complete the information obtained during the semi-structured interview. Each interview took between $1 \frac{1}{2}$ to 2 hours and was usually conducted in French, but also in English, Swahili or Lingala (all languages well understood and spoken by the interviewer). Originally we had intended to record the interviews, but none of the informants accepted to be tape-recorded. Detailed notes were taken during the interviews, and immediately written down after the interviews.

\section{Analysis}

Qualitative analysis aimed at identifying general perceptions about dietary changes and difficulties associated with migration to Geneva, and suggestions to dietary improvement. Analysis did not aim to make generalizations about dietary habits among specific migrant groups. Data tables were used to compare and contrast answers to interview questions. Supplementary quantitative information (consumption frequencies before and after migration) were tabulated and counted (Microsoft $®$ Excel 2002).

\section{Results}

\section{Sample description}

Nineteen interviews were analysed, as one respondent could not discuss all topics. Mean age (SD) was 31 (6). Other respondents' characteristics are displayed in Table 1.

\section{Perceived dietary changes following migration}

All respondents reported eating fewer fruits and vegetables, and drinking more carbonated sweetened beverages. Some respondents reported other changes, like adding breakfast cereals, decreasing the consumption of fritters, palm oil and traditional dishes, replacing goat by lamb meat, decreasing the amount of salted/smoked fish or replacing it by canned fish, adding new food items like corned beef, canned sardines, mayonnaise, chocolate and olive oil.

Less than half of the respondents ( $42 \%)$ were satisfied with their diet in Switzerland and considered food as abundant and various. The remaining $58 \%$ who were not satisfied said they were not used to cook on their own and judged their diet monotonous. They complained about constipation and weight gain which they associated with their diet and lifestyle: "Here [I have] nothing to do the whole day, so I eat a lot." They also complained about difficulties in finding affordable African food and their ignorance of local food: "The doctor recommended eating mozzarella. I had no idea what that was."

Table 1 Characteristics of the study population $(n=19)$, Geneva, 2001

\begin{tabular}{lc}
\hline & N (\%) \\
\hline Sex & \\
Female & $14(74)$ \\
Male & $5(26)$ \\
& \\
Country of origin & \\
Angola & $3(16)$ \\
Cameroon & $2(11)$ \\
Burkina Faso & $2(11)$ \\
Burundi & $1(5)$ \\
Democratic Republic of Congo & $4(21)$ \\
Ethiopia & $3(16)$ \\
Kenya & $2(11)$ \\
Rwanda & $1(5)$ \\
Tanzania & $1(5)$ \\
Education level & \\
University degree & $4(21)$ \\
Professional or college degree & $13(68)$ \\
Primary school & $2(11)$ \\
Comprehension/expression in French & \\
Good & $10(53)$ \\
Average & $9(47)$ \\
\hline
\end{tabular}




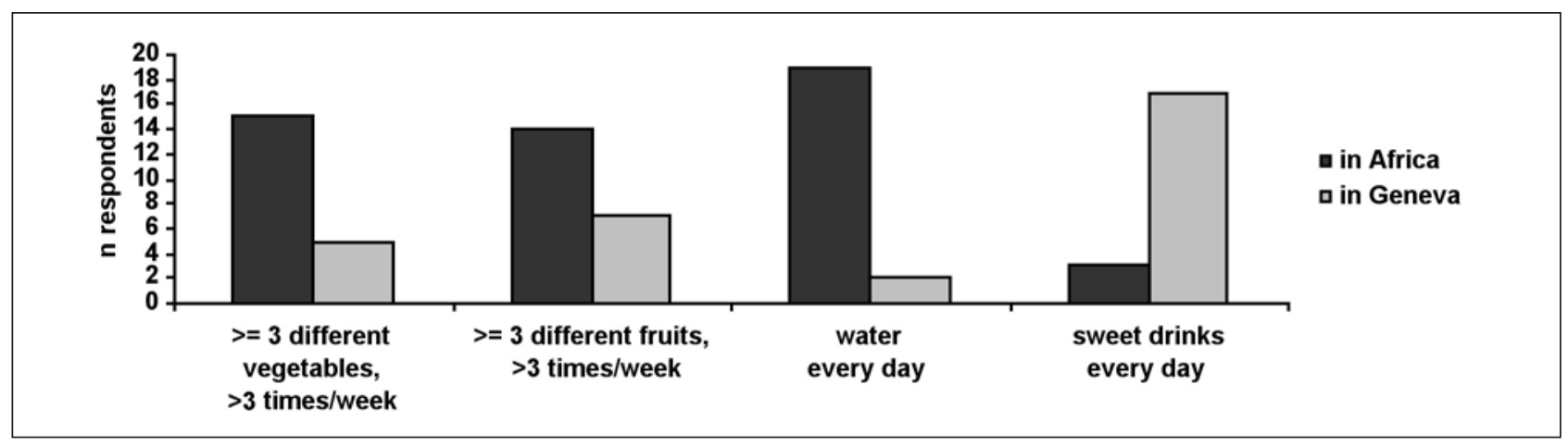

Figure1 Distribution of frequent intake of vegetables (except onions and tomatoes), fruits and beverages among 19 African asylum seekers, in country of origin and in Geneva

Reduction in vegetable and fruit consumption

Food diversity decreased after arrival in Switzerland, especially for vegetables and fruits. In Africa, 17 different vegetables and 10 different fruits were regularly consumed by the respondents. Seven vegetables and eight fruits were no longer consumed in Switzerland. Two vegetables (lettuce and bette - a leafy vegetable) and one fruit (grapes) were introduced after arrival in Switzerland.

In Africa, 15 of the respondents (79\%) consumed at least three different vegetables (excluding tomatoes and onions) more than three times per week, as opposed to only five respondents $(26 \%)$ after arrival in Geneva. The same scheme was observed for fruits (14 and seven respondents respectively) (Fig. 1).

Increase in sweetened beverages (soft drinks)

In Africa, all respondents used to drink boiled or tap water daily. Soft drinks were consumed daily by three respondents and only occasionally for the others. Upon arrival in Switzerland, all but two respondents switched from tap water to sweetened beverages such as soft drinks, ice-tea, and lemonades (Fig. 1).

\section{Informants' explanations for dietary changes}

Respondents had difficulties in finding African vegetables, which, when available, were considered very expensive. Some were replaced by local ones (lettuce or bette instead of manioc leaves for example) but respondents expressed their hopelessness in front of the vegetable rack: "I don't know those products, I don't know the names so I cannot weigh them ${ }^{1}$. Or I buy something and I throw it away because I don't know how to cook it." Price and taste were other reasons to stop buying some food items, especially fruits. Choices of soft drinks were considered awesome by the respondents. Respondents

${ }^{1}$ In Geneva, self weighing of vegetable is used in most supermarkets. considered that accessibility and advertisements encouraged them to consume these items, which were comparatively cheaper than in their home country. As one respondent stated it: "There is such a choice of soft drinks here, you hardly see anything else in the shops; and the children love them!"

\section{Opportunities for improvement}

Although informants felt that significant economic and cultural barriers prevented them from improving their diet, they did suggest a number of interventions that might help them to overcome these barriers. Suggestions included organised supermarket visits to help them learn about local foods; written food lists to display equivalencies between African and local food items, and cooking courses to teach them how to prepare local foods and to use local foods in traditional dishes. They also indicated that an increase in their allowance would be useful to improve their diet.

\section{Discussion}

Our study found that African asylum seekers were aware of and concerned about changes in their diet since migration to Geneva. Although the study interviewed only a small convenience sample of informants, results do suggest that standard nutrition education would not address the main needs and concerns of this population. Rather, our study suggests that nutritional interventions for this population need to focus on familiarizing asylum seekers with the names, uses and preparation of local foods.

\section{Study limitations}

Our study only explored perceptions of dietary changes and problems. It lacked objective measures of actual diet modification. The development and validation of a quantitative questionnaire for this diverse study population would have been time-consuming and difficult, and would not have 
served our purpose (MacIntyre et al. 2001). However, future interventions may necessitate such quantitative baseline data and tools to assess their impact.

This small scale study however was a good starting point to identify the concerns of our target population, and document anecdotal reports from the nurses of the Health Centre for Migrants. It demonstrates that such rapid assessment is feasible and provides invaluable information to design cultural sensitive approaches to dietetic intervention.

\section{Perspectives}

Future interventions should be directed towards both the migrants themselves and the health care personnel. Supermarket visits and group classes integrating more and less ac-

Zusammenfassung

Ernährungsveränderungen von afrikanischen Flüchtlingen nach deren Migration nach Genf: eine kurze Ernährungserhebung zur Entwicklung von Ernährungsinterventionen Fragestellung: Erhebung von individuell wahrgenommenen Ernährungsveränderungen und -problemen bei afrikanischen Asylsuchenden, um zielgruppenspezifische Ernährungserziehungsmassnahmen entwickeln zu können.

Methoden: Eine qualitative Querschnittstudie in einer zweckbestimmten Stichprobe. In den Analysen wurden berichtete Ernährungsveränderungen den migrationsbedingten Schwierigkeiten vergleichend gegenübergestellt.

Ergebnisse: Neunzehn Interviews wurden analysiert. Nach der Migration nahm die Anzahl der verschiedenen wöchentlich verzehrten Früchte und Gemüse von 10 auf zwei bzw. von 17 auf 10 ab. Die Zahl der Studienteilnehmer, die häufiger als dreimal pro Woche Süssgetränke konsumieren, stieg von drei auf 18. Gründe die mit diesen Veränderungen in Zusammenhang stehen sind Preis, Geschmack, Produktangebot und Verfügbarkeit.

Schlussfolgerung: Diese Ernährungsveränderungen könnten ernsthafte gesundheitliche Folgen nach sich ziehen. Hilfsmassnahmen, die den Vorschlägen der Studienteilnehmer Rechnung tragen, könnten problemlos eingeführt werden. culturated persons could increase refugees' familiarity with the local food items, and their awareness of marketing "tricks" (Rodgers et al. 1994). Workshops could focus on knowledge about nutrition and health, and give occasions to practice their recipes with local foods (Kruseman et al. 2003). A budget management course may be a practical and realistic alternative to financial allowance increase. Additionally, making health care professionals more aware of the changes, the reasons of those changes and the cultural dimension of their interaction with migrants may improve the impact of their prevention messages (Curry 2000; Gordon 2001). Next steps should include the development and piloting of such intervention approaches.

Résumé

Changements alimentaires chez des réfugiés africains à Genève: une évaluation brève afin d'orienter des interventions nutritionnelles

Objectifs: Evaluer les changements et problèmes alimentaires perçus par des réfugiés africains, dans le but de développer des interventions d'éducation nutritionnelle appropriées.

Méthodes: Etude transversale qualitative au sein d'un échantillon de convenance. Les modifications de l'alimentation rapportées comme liées à la migration ont été recensées, groupées et comparées.

Résultats: Dix-neuf interviews ont été analysées. Après la migration, les principaux changements alimentaires étaient la réduction du nombre de fruits et légumes différents consommés hebdomadairement de 10 à 2 , et de 17 à 10 respectivement. Le nombre de répondants consommant des boissons sucrées plus de 3 fois par semaine est passé de 3 à 18. Des raisons de prix, de goût et d'accessibilité étaient évoquées pour expliquer ces changements.

Conclusion: Ces changements alimentaires pourraient avoir des conséquences sanitaires sérieuses. Des interventions simples basées sur les suggestions des répondants devraient être envisagées. 


\section{References \\ Curry KR (2000). Multicultural competence in dietetics and nutrition. J Am Diet Assoc 100: 1142-3. \\ Gordon L (2001). Multicultural competence: beyond the basics. J Am Diet Assoc 101: 520. \\ Hargreaves MK, Schlundt DG, Buchowski MS (2002). Contextual factors influencing the eating behaviours of African American women: a focus group investigation. Ethn Health 7: 133-47.}

Harris-Davis E, Haughton B (2000). Model for multicultural nutrition counseling competencies. J Am Diet Assoc 100: 1178-85.

He J, Klag MJ, Wu Z, et al. (1996). Effect of migration and related environmental changes on serum lipid levels in southwestern Chinese men. Am J Epidemiol 144: 839-48.

Kruseman M, Stoll BE, Stalder H (2003). Interactive group education for refugees from the Former Yugoslavia to improve their diet. Patient Educ Couns 49: 171-6.
MacIntyre UE, Venter CS, Vorster HH (2001). A culture-sensitive quantitative food frequency questionnaire used in an African population: 1.

Development and reproducibility. Public Health Nutr 4: 53-62.

Misra R, Patel TG, Davies D, Russo T (2000). Health promotion behavior of Gujurati Asian Indian immigrants in the United States. J Immigrant Health 2: 223-30.

Raymond NR, D'Eramo-Melkus G (1993). Noninsulin-dependent diabetes and obesity in the black and Hispanic population: culturally sensitive management. Diabetes Educ 19: 313-7.

Rodgers AB, Kessler LG, Portnoy B, et al. (1994). "Eat for Health": a supermarket intervention for nutrition and cancer risk reduction. Am J Public Health 84: 72-6.

Satia-Abouta J, Patterson RE, Neuhouser ML, Elder $J$ (2002). Dietary acculturation: applications to nutrition research and dietetics. J Am Diet Assoc 102: 1105-18.

Satia JA, Patterson RE, Taylor VM, et al. (2000). Use of qualitative methods to study diet, acculturation, and health in Chinese-American women. J Am Diet Assoc 100: 934-40.
Sundquist J, Winkleby M (2000). Country of birth, acculturation status and abdominal obesity in a national sample of Mexican-American women and men. Int J Epidemiol 29: 470-7.

Trostler N (1997). Health risks of immigration: the Yemenite and Ethiopian cases in Israel. Biomed Pharmacother 51: 352-9.

\section{Conflict of interest}

None. No funding was received for this project.

Address for correspondence

Maaike Kruseman, MPH, Diet. Dipl. Scientific collaborator

Department of community medicine University Hospitals of Geneva

24 rue Micheli-du-Crest

CH-1211 Geneva 14

Tel.: +41 223729415

Fax: +4122 3729359

e-mail: Maaike.Kruseman@hcuge.ch 